\title{
Pengaruh Disiplin Terhadap Kinerja Karyawan PT. Prima Arga Cemerlang
}

\author{
Okta Nikada ${ }^{1}$, Diana Azwina ${ }^{2}$ \\ ${ }^{1}$ Mahasiswa Manajemen (NIM. 2014052294), Universitas Pamulang; oktanikada@ gmail.com \\ ${ }^{2}$ Fakultas Ekonomi, Universitas Pamulang; dosen01741@unpam.ac.id*
}

Received 13 Februari 2021| Revised 09 Maret 2021 | Accepted 25 Maret 2021

*Korespondensi Penulis

\begin{abstract}
Abstrak
Penelitian ini bertujuan untuk mengetahui pengaruh Disiplin terhadap Kinerja Karyawan PT. Prima Arga Cemerlang. Penelitian ini merupakan penelitian asosiatif sekaligus penelitian deskriptif dengan pendekatan kuantitatif. Populasi dalam penelitian ini adalah karyawan PT. Prima Arga Cemerlang yang masih aktif bekerja, sebanyak 40 (Empat Puluh) orang. Pengambilan sampel menggunakan metode sampling jenuh sehingga sampel pada penelitian ini berjumlah 40 (Empat Puluh) orang. Teknik analisis data menggunakan uji deskriptif, koefisien korelasi, koefisien determinasi, uji regresi linier sederhana, dan uji hipotesis/uji signifikansi t. Nilai Koefisien Korelasi sebesar 0.861 menunjukkan adanya korelasi yang positif dan sangat kuat antara Variabel Disiplin denganVariabel Kinerja Karyawan. Nilai Koefisien Determinasi menunjukkan bahwa Variabel Disiplin memberikan kontribusi terhadap Variabel Kinerja Karyawan PT. Prima Arga Cemerlang sebesar 74,2\% dan sisanya 25,8\% dipengaruhi variabel lain yang tidak diteliti. Uji regresi linier sederhana menghasilkan persamaan $\mathrm{Y}=3,182+0,919 \mathrm{X}$, yang berarti hubungan antara Variabel Disiplin dan Variabel Kinerja Karyawan bersifat positif. Artinya jika Variabel Disiplin ditingkatkan, maka Variabel Kinerja Karyawan akan meningkat pula. Dari uji hipotesis/uji signifikansi t diperoleh nilai $t_{\text {hitung }}(10,451)>t_{\text {tabel }}(1,686)$. Hal ini berarti terdapat pengaruh antara Variabel Disiplin terhadap Variabel Kinerja Karyawan PT. Prima Arga Cemerlang.
\end{abstract}

Kata kunci: Disiplin; Kinerja

\begin{abstract}
This study aims to determine the effect of discipline on employee performance at PT. Prima Arga Cemerlang. This research is an associative research as well as a descriptive study with a quantitative approach. The population in this study were employees of PT. Prima Arga Cemerlang who are still actively working, as many as 40 (forty) people. Sampling using saturated sampling method so that the sample in this study amounted to 40 (forty) people. The data analysis technique used descriptive test, correlation coefficient, determination coefficient, simple linear regression test, and hypothesis test / significance test $t$. The Correlation Coefficient value of 0.861 indicates a positive and very strong correlation between Discipline Variables and Employee Performance Variables. The value of the coefficient of determination shows that the variable of discipline contributes to the variable performance of employees of PT. Prima Arga Cemerlang at $74.2 \%$ and the remaining $25.8 \%$ is influenced by other variables not researched. The simple linear regression test produces the equation $Y=3.182+0.919 X$, which means that the relationship between Discipline Variables and Employee Performance Variables is positive. This means that if the Discipline Variable is increased, the Employee Performance Variable will also increase. From the hypothesis test / $t$ significance test, the value $t$ count (10.451)> t table (1.686) is obtained. This means that there is an influence between Discipline Variables on Employee Performance Variables of PT. Prima Arga Cemerlang.
\end{abstract}

Keywords: Discipline; Performance 


\section{PENDAHULUAN}

Pada era globalisasi saat ini, persaingan industri yang semakin sengit dengan hadirnya beragam peluang sekaligus ancaman menjadi suatu fenomena yang tidak dapat dihindari oleh pelaku usaha. Sebagai pelaku usaha, organisasi harus memiliki sumber daya yang memadai agar dapat memenangkan persaingan usaha. Salah satu sumber daya terpenting yang perlu diperhatikan dalam kelangsungan kegiatan berorganisasi adalah human resources (Sumber Daya Manusia/SDM). SDM memiliki peran penting sebagai penggerak sumber daya lainnya dalam menjalankan roda organisasi guna mencapai tujuan-tujuan organisasi yang telah ditetapkan. Di sisi lain, sebagai satu-satunya sumber daya organisasi yang memiliki kebutuhan sebagai makhluk hidup, SDM harus mendapatkan perhatian dan perlakuan khusus serta dipenuhi kebutuhannya. Tidak dapat dipungkiri bahwa tujuan SDM sebagai pegawai berbeda dengan tujuan organisasi. Oleh karenanya, untuk dapat memberikan kontribusi sesuai kebutuhan organisasi, penting bagi organisasi untuk memenuhi kebutuhan SDM terlebih dahulu, mulai dari kebutuhan dasar hingga kebutuhan akan pengakuan. Hal ini sejalan dengan Teori Hierarki Kebutuhan Abraham Maslow dalam Goble (1995:30) yang menyatakan bahwa "terdapat 5 (lima) tingkat kebutuhan manusia yaitu kebutuhan fisiologis, kebutuhan akan rasa aman, kebutuhan akan rasa dan kasih sayang, kebutuhan akan penghargaan, dan kebutuhan akan aktualisasi diri". Ketika kebutuhan SDM telah terpenuhi, maka harapan organisasi untuk mendapatkan kontribusi yang berkualitas baik dari SDM dapat direalisasikan. Seiring dengan hal tersebut, perlu dilakukan upaya peningkatan kualitas SDM. Salah satu upaya yang dapat dilakukan organisasi adalah dengan memberikan pelatihan.

Gambaran tersebut didasarkan pada pertimbangan bahwa apabila proses bisnis organisasi dijalankan oleh SDM yang memiliki kualitas buruk, maka organisasi akan kesulitan untuk mencapai tujuan yang telah ditetapkan. Namun apabila proses bisnis organisasi dijalankan oleh SDM yang memiliki kualitas baik, kelangsungan proses bisnis akan berjalan lebih optimal sehingga tujuan organisasi akan lebih mudah untuk dicapai. Pendapat ini di dukung oleh Hasibuan (2016:50) bahwa
"Manajemen adalah ilmu tentang sekumpulan pengetahuan yang sistematis, telah dikumpulkan dan diterima secara umum dengan suatu objek atau objek tertentu dan seni (suatu kreativitas, pribadi yang kuat dan disertai keterampilan) mengatur, memanfaatkan Sumber Daya Manusia dan Sumber Daya lainnya secara efektif dan efisien untuk mencapai suatu tujuan tertentu.

Selanjutnya, ketika kontribusi yang maksimal sudah diberikan SDM yang selanjutnya disebut karyawan, maka dapat dikatakan bahwa karyarawn sudah menunjukkan kinerja yang baik. Kinerja karyawan yang baik akan memberikan dukungan bagi peningkatan kinerja organisasi yang selanjutnya disebut perusahaan.

Menurut Bangun (2012:231) "kinerja merupakan hasil pekerjaan yang dicapai seseorang berdasarkan persyaratan pekerjaan". Lalu Mangkunegara (2012:9) mengemukakan bahwa "kinerja adalah hasil kerja secara kualitas dan kuantitas yang dicapai oleh seorang karyawan dalam melaksanakan tugasnya sesuai dengan tanggung jawab yang diberikan kepadanya". Menurut Moeheriono (2012:95) "kinerja atau performance merupakan gambaran mengenai tingkat pencapaian pelaksanaan suatu program kegiatan atau kebijakan dalam mewujudkan sasaran, tujuan, visi dan misi organisasi yang dituangkan melalui perencanaan strategis suatu organisasi". Kinerja karyawan merupakan perilaku nyata yang ditampilkan setiap karyawan sebagai prestasi kerja yang dihasilkan sesuai dengan perannya dalam perusahaan. Setiap orang yang bekerja atau dalam suatu kelompok kerja, selalu diharapkan untuk dapat menghasilkan kinerja yang baik dari sisi kualitas maupun kuantitasnya.

Berdasarkan analisis penulis terhadap kinerja karyawan PT. Prima Arga Cemerlang yang berlokasi di Jl.Permata Raya No.57 RT.005/RW.015, Tanah Tinggi, Tangerang, Banten, terlihat adanya fenomena penurunan kinerja karyawan, baik dari sisi kualitas maupun kuantitas, terjadinya peningkatan ketidakdisiplinan karyawan, tidak dipatuhinya batas waktu penyelesaian pekerjaan yang sudah ditetapkan, serta kekurangmampuan karyawan untuk melakukan kerja sama tim. Di samping itu, secara teknis, setiap karyawan diharapkan untuk melakukan pekerjaannya secara efektif 
dan efisien untuk mencapai standar kualitas yang ditetapkan perusahaan. Namun, dalam pelaksanaannya, yang sering terjadi, karyawan tidak memenuhi target perusahaan. Hal ini tercermin dalam tabel 1 . berikut ini.

Tabel 1. Data Penjualan Produk PT. Prima Arga Cemerlang

Tahun2016-2017

\begin{tabular}{cccccc}
\hline \multirow{2}{*}{ No } & \multirow{2}{*}{ Tahun } & \multirow{2}{*}{ Target } & \multicolumn{2}{c}{ Pencapaian } & \multirow{2}{*}{ Keterangan } \\
\cline { 4 - 5 } 1 & 2016 & 4.000 .000 .000 & 3.280 .000 .000 & $82 \%$ & Tidak Tercapai \\
\hline 2 & 2017 & 4.000 .000 .000 & 3.840 .000 .000 & $96 \%$ & Tidak Tercapai \\
\hline 3 & 2018 & 5.000 .000 .000 & 4.400 .000 .000 & $88 \%$ & Tidak Tercapai \\
\hline
\end{tabular}

Sumber: PT. Prima Arga Cemerlang

Berdasarkan tabel 1. terlihat bahwa karyawan tidak memenuhi target yang telah ditetapkan perusahaan. Kondisi di tahun 2016 dapat diperbaiki dengan adanya peningkatan di tahun 2017, namun terjadi penurunan di tahun 2018.

Berdasarkan analisis penulis selanjutnya, secara umum dapat diidentifikasi beberapa faktor penyebab menurunnya kinerja karyawan pada PT Prima Arga Cemerlang yakni rendahnya tingkat disiplin karyawan, dilanggarnya ketentuan mengenai tempat untuk mencatat kehadiran, kurangnya kesadaran karyawan akan pentingnya prestasi, terlambatnya proses penyelesaian pekerjaan dibandingkan dengan target waktu yang telah ditetapkan perusahaan. Di sisi lain, kurangnya perhatian perusahaan akan kebutuhan penghargaan bagi karyawan dalam bentuk jenjang karir serta tidak tegasnya peraturan mengenai pelanggaran disiplin waktu kerja membuat karyawan tidak merasa perlu untuk memperbaiki perilakunya. Sebagai contoh, meskipun waktu kerja sudah ditetapkan pukul 09:00 sampai dengan pukul 18:00, namun banyak karyawan yang mengabaikannya. Sanksi yang diterima pun relatif ringan yaitu pemotongan upah kerja yang kecil. Diantara beberapa faktor penyebab fluktuatifnya kinerja, penulis akan memfokuskan pada rendahnya tingkat kedisiplinan.

Hasibuan dalam Barnawi dan Arifin (2012:112) mengemukakan "disiplin merupakan kemampuan kerja seseorang untuk secara teratur, tekun, terus-menerus, dan bekerja sesuai dengan aturan-aturan yang berlaku dengan tidak melanggar aturan-aturan yang sudah ditetapkan. Disiplin yang rendah pada umumnya akan berpengaruh terhadap kualitas kerja yang rendah pula. Sedangkan di sisi lain, perusahaan dituntut mendorong tingginya kinerja karyawan agar berpengaruh positif terhadap kinerja perusahaan secara menyeluruh. Kinerja karyawan yang baik salah satunya di hasilkan oleh kedisiplinan kerja dan integritas yang tinggi. Berkaitan dengan hal tersebut, berikut disampaikan data ketidakdisiplinan karyawan PT Prima Arga Cemerlang tahun 2016-2018.

Tabel 2. Data Jumlah Karyawan PT. Prima Arga Cemerlang yang datang Terlambat Tahun 2016 - 2018

\begin{tabular}{cllcc}
\hline \multirow{2}{*}{ Tahun } & Bulan & $\begin{array}{c}\text { Total } \\
\text { Karyawan }\end{array}$ & $\begin{array}{c}\text { Karyawan yang } \\
\text { datang } \\
\text { Terlambat }\end{array}$ & Persentase \\
\hline \multirow{1}{*}{2018} & Januari & 38 & 16 & $42 \%$ \\
\cline { 2 - 5 } & Februari & 40 & 11 & $28 \%$ \\
\cline { 2 - 5 } & Maret & 40 & 12 & $30 \%$ \\
\cline { 2 - 5 } & April & 40 & 18 & $35 \%$ \\
\cline { 2 - 5 } & Mei & 40 & 15 & $38 \%$ \\
\cline { 2 - 5 } & Juni & 40 & 15 & $35 \%$ \\
\cline { 2 - 5 } & Juli & 41 & 10 & $39 \%$ \\
\cline { 2 - 5 } & Agustus & 43 & 16 & \\
\cline { 2 - 5 } & September & 41 & & \\
\hline
\end{tabular}


Okta Nikada \& Diana Azwina: Pengaruh Disiplin Terhadap Kinerja Karyawan PT. Prima Arga Cemerlang

\begin{tabular}{|c|c|c|c|c|}
\hline Tahun & Bulan & $\begin{array}{c}\text { Total } \\
\text { Karyawan }\end{array}$ & $\begin{array}{c}\text { Karyawan yang } \\
\text { datang } \\
\text { Terlambat } \\
\end{array}$ & Persentase \\
\hline \multirow{15}{*}{2017} & Oktober & 41 & 12 & $30 \%$ \\
\hline & November & 41 & 11 & $27 \%$ \\
\hline & Desember & 40 & 18 & $45 \%$ \\
\hline & Januari & 40 & 15 & $38 \%$ \\
\hline & Februari & 40 & 16 & $40 \%$ \\
\hline & Maret & 40 & 12 & $30 \%$ \\
\hline & April & 40 & 20 & $50 \%$ \\
\hline & Mei & 42 & 15 & $36 \%$ \\
\hline & Juni & 42 & 14 & $33 \%$ \\
\hline & Juli & 42 & 14 & $33 \%$ \\
\hline & Agustus & 42 & 13 & $31 \%$ \\
\hline & September & 41 & 16 & $39 \%$ \\
\hline & Oktober & 41 & 12 & $29 \%$ \\
\hline & November & 41 & 12 & $29 \%$ \\
\hline & Desember & 41 & 14 & $34 \%$ \\
\hline \multirow{12}{*}{2016} & Januari & 41 & 12 & $29 \%$ \\
\hline & Februari & 41 & 10 & $24 \%$ \\
\hline & Maret & 41 & 14 & $34 \%$ \\
\hline & April & 41 & 12 & $29 \%$ \\
\hline & Mei & 40 & 13 & $33 \%$ \\
\hline & Juni & 40 & 14 & $35 \%$ \\
\hline & Juli & 40 & 15 & $38 \%$ \\
\hline & Agustus & 40 & 11 & $28 \%$ \\
\hline & September & 38 & 8 & $21 \%$ \\
\hline & Oktober & 38 & 13 & $34 \%$ \\
\hline & November & 38 & 11 & $29 \%$ \\
\hline & Desember & 38 & 11 & $29 \%$ \\
\hline
\end{tabular}

Sumber: Data internal PT. Prima Arga Cemerlang

Tabel 2. memperlihatkan fluktuasi jumlah karyawan yang datang terlambat yang berkisar antara $27 \%$ sampai dengan $42 \%$ setiap bulannya sejak tahun 2016 sampai dengan tahun 2018. Selanjutnya tabel 3. memperlihatkan ketidakdisiplinan karyawan dalam aspek penyelesaian pekerjaan.

Tabel 3. Data Durasi Keterlambatan penyelesaian Pekerjaan Karyawan

PT. Prima Arga Cemerlang Tahun 2016 - 2018

\begin{tabular}{rccccc}
\hline \multirow{2}{*}{ Tahun } & Bulan & $\begin{array}{c}\text { Durasi Waktu } \\
\text { Target } \\
\text { Penyelesaian } \\
\text { Pekerjaan (Jam) }\end{array}$ & $\begin{array}{c}\text { Realisasi } \\
\text { penyelesian } \\
\text { Pekerjaan } \\
(\text { Jam) }\end{array}$ & $\begin{array}{c}\text { Keterlambatan } \\
(\text { Jam })\end{array}$ & $\%$ \\
\hline \multirow{3}{*}{2018} & 160 & 210 & 50 & $32 \%$ \\
\cline { 2 - 6 } & Januari & 160 & 190 & 30 & $19 \%$ \\
\cline { 2 - 6 } & Februari & 160 & 180 & 20 & $13 \%$ \\
\cline { 2 - 6 } & Maret & 160 & 190 & 30 & $19 \%$ \\
\cline { 2 - 6 } & April & 160 & 170 & 10 & $7 \%$ \\
\hline
\end{tabular}




\begin{tabular}{|c|c|c|c|c|c|}
\hline Tahun & Bulan & $\begin{array}{c}\text { Durasi Waktu } \\
\text { Target } \\
\text { Penyelesaian } \\
\text { Pekerjaan (Jam) }\end{array}$ & $\begin{array}{c}\text { Realisasi } \\
\text { penyelesian } \\
\text { Pekerjaan } \\
(\text { Jam }) \\
\end{array}$ & $\begin{array}{c}\text { Keterlambatan } \\
\text { (Jam) }\end{array}$ & $\%$ \\
\hline \multirow{18}{*}{2017} & Juli & 160 & 180 & 20 & $13 \%$ \\
\hline & Agustus & 160 & 160 & 0 & $0 \%$ \\
\hline & September & 160 & 160 & 0 & $0 \%$ \\
\hline & Oktober & 160 & 190 & 30 & $19 \%$ \\
\hline & November & 160 & 180 & 20 & $13 \%$ \\
\hline & Desember & 160 & 220 & 60 & $38 \%$ \\
\hline & Januari & 160 & 200 & 40 & $25 \%$ \\
\hline & Februari & 160 & 220 & 60 & $38 \%$ \\
\hline & Maret & 160 & 190 & 30 & $19 \%$ \\
\hline & April & 160 & 190 & 30 & $19 \%$ \\
\hline & Mei & 160 & 160 & 0 & $0 \%$ \\
\hline & Juni & 160 & 190 & 30 & $19 \%$ \\
\hline & Juli & 160 & 180 & 20 & $13 \%$ \\
\hline & Agustus & 160 & 170 & 10 & $6 \%$ \\
\hline & September & 160 & 170 & 10 & $6 \%$ \\
\hline & Oktober & 160 & 190 & 30 & $19 \%$ \\
\hline & November & 160 & 160 & 0 & $0 \%$ \\
\hline & Desember & 160 & 200 & 40 & $25 \%$ \\
\hline \multirow{12}{*}{2016} & Januari & 160 & 160 & 0 & $0 \%$ \\
\hline & Februari & 160 & 200 & 40 & $25 \%$ \\
\hline & Maret & 160 & 210 & 50 & $31 \%$ \\
\hline & April & 160 & 200 & 40 & $25 \%$ \\
\hline & Mei & 160 & 190 & 30 & $19 \%$ \\
\hline & Juni & 160 & 280 & 120 & $75 \%$ \\
\hline & Juli & 160 & 170 & 10 & $6 \%$ \\
\hline & Agustus & 160 & 190 & 30 & $19 \%$ \\
\hline & September & 160 & 180 & 20 & $13 \%$ \\
\hline & Oktober & 160 & 200 & 40 & $25 \%$ \\
\hline & November & 160 & 160 & 0 & $0 \%$ \\
\hline & Desember & 160 & 180 & 20 & $13 \%$ \\
\hline
\end{tabular}

Sumber: Data internal PT. Prima Arga Cemerlang

Tabel 3 memperlihatkan fluktuasi ketidakdisiplinan karyawan dalam aspek penyelesaian pekerjaan. Hampir setiap bulan terdapat keterlambatan yang berkisar antara $6 \%$ sampai dengan $75 \%$ sejak tahun 2016 sampai dengan tahun 2018.

Penelitian ini bertujuan mengetahui "Pengaruh Disiplin Terhadap Kinerja Karyawan PT. Prima Arga Cemerlang"

\section{Disiplin}

Menurut Rivai \& Sagala (2013:825) "disiplin adalah suatu alat yang digunakan para manajer untuk berkomunikasi dengan karyawan agar mereka bersedia untuk mengubah suatu perilaku dan untuk meningkatkan kesadaran juga kesediaan seseorang agar mentaati semua peraturan dan norma sosial yang berlaku di suatu perusahaan." Sementara itu Sutrisno (2014:85) menyatakan "di dalam kehidupan sehari-hari, dimanapun manusia berada dibutuhkan peraturan-peraturan dan ketentuan-ketentuan yang akan mengatur dan membatasi setiap kegiatan dan perilakunya. Namun, peraturanperaturan tersebut tidak akan ada artinya bila tidak disertai dengan sanksi bagi para pelanggaranya." Selanjutnya menurut Hasibuan (2018:193) "kedisiplinan adalah kesadaran dan kesediaaan seseorang mentaati semua peraturan perusahaan dan norma-norma sosial yang berlaku. Disiplin yang baik mencerminkan besarnya tanggung jawab seseorang terhadap tugas-tugas yang diberikan terhadapnya. Hal ini akan mendorong gairah kerja, semangat kerja dan terwujudnya tujuan organisasi." 
Dari berbagai pendapat di atas dapat disimpulkan bahwa disiplin adalah sikap dan perilaku terkendali dari seseorang atau sekelompok orang yang dilandasi kesadaran dan kesukarelaan untuk menaati segala peraturan untuk tujuan tertentu. Disiplin juga merupakan suatu sikap, tingkah laku, dan perbuatan yang sesuai dengan peraturan baik tertulis maupun tidak tertulis, dan bila melanggar akan ada sanksi atas pelanggarannya.

Sinambela (2012:239) berpendapat terdapat dua jenis disiplin, yaitu disiplin preventif dan disiplin korektif. Menurut Singodimedjo dalam Sutrisno (2015:89) faktor yang mempengaruhi disiplin karyawan adalah besar kecilnya pemberian kompensasi, ada tidaknya keteladanan pimpinan dalam organisasi, ada tidaknya aturan pasti yang dijadikan pegangan, keberanian pimpinan dalam mengambil tindakan, ada tidaknya pengawasan pimpinan. Selanjutnya Simamora dalam Sinambela (2012:243) menyatakan tujuan utama tindakan pendisiplinan adalah memastikan bahwa perilaku-perilaku karyawan konsisten dengan aturan-aturan yang ditetapkan oleh organisasi. Berbagai aturan yang di susun oleh organisasi adalah tuntunan untuk mencapai tujuan organisasi yang ditetapkan. Pada saat suatu aturan di langgar, efektivitas organisasi berkurang sampai pada tingkat tertentu, tergantung pada kerasnya pelanggaran. Tujuan berikutnya adalah menciptakan atau mempertahankan rasa hormat dan saling percaya di antara atasan dan bawahannya. Disiplin yang diberlakukan secara tidak tepat dapat menciptakan masalah-masalah seperti moral kerja yang rendah, kemarahan, dan kemauan buruk di antara pengawas dan bawahanbawahannya. Dalam kondisi seperti ini semua perbaikan dan perilaku karyawan hanya akan berlangsung singkat, dan pengawas harus mendisiplinkan kembali karyawan dalam jangka waktu yang tidak terlalu lama. Pelaksanaan tindakan disiplin yang benar tidak hanya memperbaiki perilaku karyawan, akan tetapi juga akan meminimalkan masalahmasalah pendisiplinan di masa yang akan datang melalui hubungan yang positif di antara bawahan dan atasan. Tindakan pendisiplinan juga dapat membantu karyawan supaya menjadi lebih produktif, dengan demikian dapat menguntungkannya dalam jangka waktu panjang. Tindakan pendisiplinan yang tepat dapat mendorong karyawan untuk meningkatkan kinerja yang pada akhirnya akan menghasilkan pencapaian individu.

\section{Kinerja}

Kinerja berasal dari pengertian performance. Ada pula yang mengartikan performance sebagai hasil kerja atau prestasi kerja namun sebenarnya kinerja mempunyai makna yang lebih luas, bukan hanya hasil kerja, tetapi termasuk bagaimana proses kinerja berlangsung. Menurut Wibowo ( 2016:7 ), kinerja berarti manajemen tentang bagaimana menciptakan hubungan dan memastikan komunikasi yang efektif. Lebih lanjut Bangun (2014:99) berpendapat bahwa kinerja adalah hasil pekerjaan yang di capai seseorang berdasarkan persyaratan-persyaratan pekerjaan, dimana persyaratan biasa disebut dengan standar kerja, yaitu tingkat yang diharapkan suatu pekerjaan tertentu untuk dapat diselesaikan dan diperbandingkan atas tujuan atau target yang ingin dicapai.

Dari berbagai pendapat di atas, maka dapat disimpulkan bahwa kinerja karyawan adalah prestasi kerja, atau hasil kerja (Output) baik kualitas maupun kuantitas yang dicapai karyawan persatuan periode waktu dalam melaksanakan tugas kerjanya sesuai dengan tanggng jawab yang diberikan kepadanya.

Kinerja merupakan variabel terikat (dependent variabel) yang dipengaruhi oleh banyak faktor yang mempunyai arti dalam penyampaian tujuan organisasi. Artinya, kesalahan dalam pengelolaan pada variabel bebas (independent variabel) akan berakibat pada kinerja, baik secara negatif maupun positif.

Kinerja seorang karyawan dapat dipengaruhi berbagai faktor, baik faktor eksternal maupun internal dari karyawan tersebut. Menurut Simamora dalam Mangkunegara (2012:13) kinerja pada umumnya dipengaruhi oleh tiga faktor, yaitu faktor individual, faktor psikologis, faktor organisasi. Menurut Wibowo (2016:192) tujuan dan manfaat penelitian kinerja diantaranya adalah untuk memperkenalkan perubahan, termasuk perubahan dalam organisasi, mendefinisikan tujuan, target dan sasaran untuk periode yang akan datang, memberi orang target yang tidak mungkin dapat di capai, sebagai suatu alat untuk memecat di kemudian hari, memberikan gambaran bahwa ketika organisasi menantang pekerja untuk kinerja tinggi, oragnisasi meninjau kembali kinerja 
yang lalu guna mengevaluasi dan mengaitkan dengan pengupahan, melobi penilai untuk kepentingan politis, dan bahkan akhir yang meragukan, mendapatkan kesenangan khusus, menyepakati tujuan pembelajaran, mengidentifikasi dan merencanakan untuk membangun kekuatan, mengidentifikasi dan merencanakan untuk menghilangkan kelemahan, membangun dialog konstruktif tentang kinerja yang dapat dilanjutkan setelah diskusi penilaian, membangun dialog yang ada antara manajer dengan anak buahnya, menjaga perusahaan atau pemegang saham utama agar senang tanpa menggunakan penilaian dalam menjalankan perusahaan.

\section{Penelitian Terdahulu}

Penelitian Devi Dayang Septiasari (2017) dengan judul "Pengaruh disiplin kerja terhadap kinerja pegawai pada dinas perindustrian menengah di Kota Samarinda" memperoleh hasil bahwa variabel Disiplin Kerja berpengaruh signifikan terhadap variabel Kinerja Pegawai.
Penelitian Galih Arga Nurcahya (2018) dengan judul "Pengaruh disiplin kerja terhadap kinerja karyawan PT Arah Environmental Indonesia Bag. Surakarta" diperoleh kesimpulan bahwa Kinerja Karyawan PT. Arah Enviromental Indonesia dipengaruhi oleh Disiplin Kerja.

Penelitian Cleopatra, Darwin Lie, Efendi, dan Andy Wijaya (2015) dengan judul "Pengaruh disiplin kerja terhadap kinerja karyawan pada pabrik kerupuk Naga mas Pemantangsiantar" memperoleh hasil bahwa variabel disiplin kerja mempunyai pengaruh yang sangat kuat terhadap kinerja karyawan dengan konstribusi sebesar $81,7 \%$.

\section{Kerangka Berpikir}

Menurut Sugiyono (2013: 60) "kerangka berfikir merupakan model konseptual tentang bagaimana teori berhubungan dengan berbagai faktor yang telah diidentifikasi sebagai masalah yang penting". Kerangka berpikir penelitian ini seperti ditunjukkan pada gambar 1 .

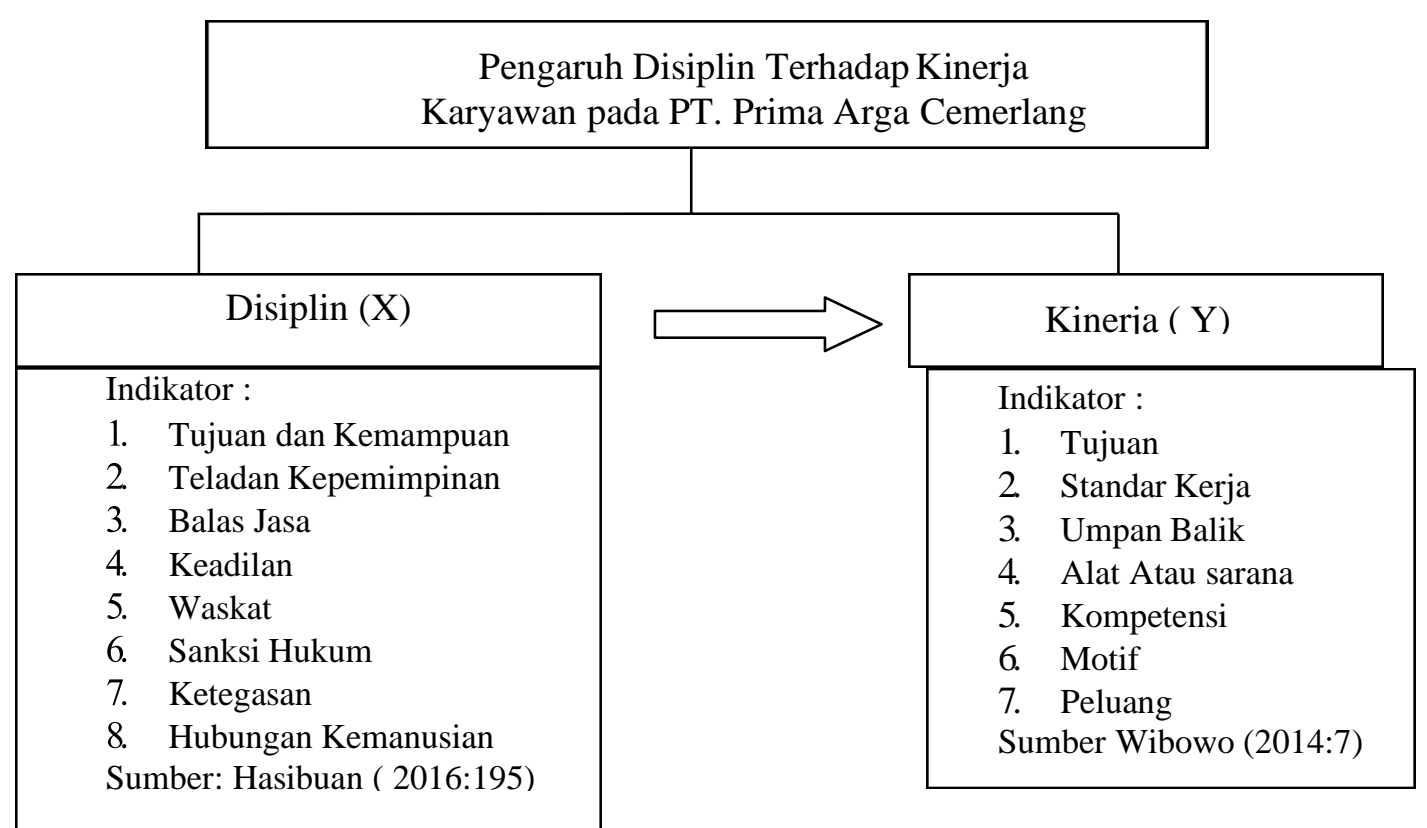

Gambar 1. Kerangka Berpikir Penelitian

\section{Hipotesis}

Hipotesis yang akan dibuktikan dalam penelitian ini adalah:
$\mathbf{H}_{\mathbf{1}}=$ terdapat pengaruh yang signifikan antara Disiplin terhadap Kinerja Karyawan PT Prima Arga Cemerlang 


\section{METODE}

Penelitian ini merupakan penelitian asosiatif yaitu penelitian yang bertujuan untuk mengetahui pengaruh atau hubungan antara dua variabel atau lebih sekaligus penelitian deskriptif dengan pendekatan kuantitatif yaitu memberi gambaran yang teratur tentang suatu kejadian dan akan dibahas dalam menganalisa data kuantitatif (data yang bersifat angka). Populasi dalam penelitian ini adalah karyawan PT. Prima Arga Cemerlang yang masih aktif bekerja, sebanyak 40 (Empat Puluh) orang. Pengambilan sampel menggunakan metode sampling jenuh. Menurut Sugiyono (2018:122) "sampel jenuh adalah teknik penentuan sampel bila semua anggota populasi digunakan sebagai sampel. Hal ini sering dilakukan bila jumlah populasi relatif kecil yang subjeknya tidak mencapai 100 (seratus) responden". Oleh karena itu sampel pada penelitian ini berjumlah 40 (Empat Puluh) orang. Teknik analisis data menggunakan uji deskriptif, koefisien korelasi, koefisien determinasi, uji regresi linier sederhana, dan uji hipotesis/uji signifikansi t.

\section{HASIL DAN PEMBAHASAN}

\section{Hasil}

\section{Uji Koefisien Korelasi}

Pengujian koefisien korelasi antara variabel Disiplin $(\mathrm{X})$ dengan variabel Kinerja Karyawan (Y) menggunakan program IBM SPSS Statistics 24 dengan analisis Correlation Coefficients Pearson dan Test Of Significance Two-Tailed dengan hasil sebagai berikut:

Tabel 4. Hasil Uji Koefisien Korelasi

\begin{tabular}{|c|c|c|c|}
\hline & & $X$ & $\mathrm{Y}$ \\
\hline \multirow[t]{3}{*}{$\mathrm{X}$} & Pearson Correlation & 1 & $.861^{\text {*** }}$ \\
\hline & Sig. (2-tailed) & & .000 \\
\hline & $\mathrm{N}$ & 40 & 40 \\
\hline \multirow[t]{3}{*}{$\mathrm{Y}$} & Pearson Correlation & $.861^{* *}$ & 1 \\
\hline & Sig. (2-tailed) & .000 & \\
\hline & $\mathrm{N}$ & 40 & 40 \\
\hline
\end{tabular}

Sumber: Data diolah 2019

Hasil pengujian koefisien korelasi menunjukkan ada korelasi antara Disiplin dengan Kinerja Karyawan sebesar $r=0.861$. Berdasarkan tabel interprestasi koefisien, korelasi tersebut masuk dalam interval 0.8001.000 dengan tingkat hubungan yang sangat kuat dan positif.

\section{Analisis Regresi Linier Sederhana}

Analisis regresi ini digunakan untuk mengetahui besarnya pengaruh disiplin terhadap kinerja karyawan. Perhitungan dalam penelitian ini menggunakan program IBM SPSS Statistics 24 dengan hasil sebagai berikut:

Tabel 5. Hasil Analisis Regresi Linier Sederhana

Coefficients $^{\text {a }}$

\begin{tabular}{|c|c|c|c|c|c|c|}
\hline & \multirow[t]{2}{*}{ Model } & \multicolumn{2}{|c|}{$\begin{array}{c}\text { Unstandardized } \\
\text { Coefficients }\end{array}$} & \multirow{2}{*}{$\begin{array}{c}\text { Standardized } \\
\text { Coefficients } \\
\text { Beta }\end{array}$} & \multirow[t]{2}{*}{$\mathrm{T}$} & \multirow[t]{2}{*}{ Sig. } \\
\hline & & B & Std. Error & & & \\
\hline \multirow[t]{2}{*}{1} & (Constant) & 3.182 & 3.955 & & .805 & .426 \\
\hline & Disiplin & .919 & .088 & .861 & 10.451 & .000 \\
\hline
\end{tabular}

a. Dependent Variable: Kinerja

Sumber: Data diolah 2019

Berdasarkan tabel di atas, diketahui nilai Constant (a) sebesar 3,182 sedang nilai Insentif (b/koefisien regresi) sebesar 0.919 Sehingga dihasikan persamaan regresinya sebagai berikut: $Y=3,182+\mathbf{0 , 9 1 9} X$

Dari persamaan regresi linier sederhana diatas dapat diinterpretasikan konstanta sebesar 3,182 menyatakan bahwa jika Variabel Disiplin (X) tidak ada/dianggap sama dengan nol, maka terdapat nilai Kinerja Karyawan (Y) sebesar 0,919. Koefisien regresi 0,919 berarti perubahan 1 unit variabel Disiplin (X) akan mengakibatkan perubahan variabel Kinerja Karyawan (Y) sebesar 0,919. 


\section{Uji Koefisien Determinasi (R2)}

Uji koefisien determinasi dilakukan untuk mengetahui besar prosentase pengaruh variabel independen (Disiplin) terhadap perubahan variabel dependen (Kinerja Karyawan).

Tabel 6. Uji Koefisien Determinasi $\left(\mathbf{R}^{2}\right)$

Koefisien Determinasi $\left(\mathbf{R}^{2}\right)$

\begin{tabular}{lcccc}
\hline Model & $\mathrm{R}$ & $\mathrm{R}$ Square & $\begin{array}{c}\text { Adjusted } \mathrm{R} \\
\text { Square }\end{array}$ & Std. Error of the Estimate \\
\hline 1 & $.861^{\mathrm{a}}$ & .742 & .735 & 1.857 \\
\hline a. Predictors: (Constant), Disiplin & & \\
Sumber: Data diolah 2019 & &
\end{tabular}

Besarnya nilai pengaruh variabel independen (Disiplin) ditunjukkan oleh nilai koefisien determinasi ( $\mathrm{R}$ Square) sebesar 0,742 . Hal ini berarti pengaruh variabel independen (Disiplin) terhadap variabel dependen (Kinerja Karyawan) adalah sebesar $74,2 \%$ dan sisanya $25,8 \%$ dipengaruhi oleh faktor lain.

\section{Uji Hipotesis/Uji Signifikan (t)}

Uji hipotesis/Uji signifikan t/ parsial/ individual digunakan untuk menguji/ mengetahui seberapa jauh pengaruh variabel independen secara individual dalam menerangkan variasi variabel dependen, dengan menggunakan significance level $\alpha=$ $5 \%$.

Tabel 7. Hasil UjiHipotesis/Uji Signifikan (t)

\begin{tabular}{|c|c|c|c|c|c|c|}
\hline & \multirow[t]{2}{*}{ Model } & \multicolumn{2}{|c|}{ Unstandardized Coefficients } & \multirow{2}{*}{$\begin{array}{c}\begin{array}{c}\text { Standardized } \\
\text { Coefficients }\end{array} \\
\text { Beta } \\
\end{array}$} & \multirow[t]{2}{*}{$\mathrm{t}$} & \multirow[t]{2}{*}{ Sig. } \\
\hline & & $\mathrm{B}$ & Std. Error & & & \\
\hline \multirow[t]{2}{*}{1} & (Constant) & 3.182 & 3.955 & & .805 & .426 \\
\hline & Kinerja Karyawan & .919 & .088 & .861 & 10.451 & .000 \\
\hline
\end{tabular}

a. Dependent Variable: Disiplin

Sumber: Data diolah 2019

Berdasarkan hasil uji signifikan $(t)$ diatas, diperoleh hasil: $t_{\text {hitung }}(10.451)>t_{\text {tabel }}$ $(1,686)$, dengan nilai signifikansi $(0.000)<$ taraf signifikansi $(0,05)$. Dengan demikian maka $\mathrm{H}_{0}$ ditolak dan $\mathrm{H}_{a}$ diterima (terdapat pengaruh Disiplin terhadap kinerja karyawan PT. Prima Arga Cemerlang). Hal ini menunjukkan pula bahwa pengaruh Disiplin signifikan terhadap Kinerja Karyawan pada PT. Prima Arga Cemerlang.

\section{Pembahasan}

Hasil uji signifikan (t) pengaruh disiplin terhadap kinerja karyawanmenunjukkan bahwa Disiplin berpengaruh terhadap Kinerja Karyawan dengan $t_{\text {hitung }}(10.451)>t_{\text {tabel }}(1,686)$ dan nilai signifikansi $(0.000)<$ taraf signifikansi $(0,05)$. Hasil pengujian koefisien korelasi menunjukkan ada korelasi antara Disiplin dengan Kinerja Karyawan sebesar $\mathrm{r}=$ 0.861 (sangat kuat dan positif). Hasil pengujian koefisien determinasi menunjukkan bahwa pengaruh variabel independen yaitu Disiplin (X) terhadap variabel dependen yaitu Kinerja Karyawan adalah sebesar $74,2 \%$ dan sisanya 25,8\% dipengaruhi oleh faktor lain.

Hasil penelitian ini sejalan dengan penelitian yang dilakukan Devi Dayang Septiasari (2017) Galih Arga Nurcahya dan Fetty Poerwita Sary (2018) dan Cleopatra, Darwin Lie, Efendi, dan Andy Wijaya (2015) bahwa disiplin kerja berpengaruh terhadap kinerja karyawan

\section{SIMPULAN}

Berdasarkan hasil dan pembahasan penelitian dapat disimpulkan:

Hasil uji signifikan (t) menunjukkan bahwa Disiplin berpengaruh terhadap Kinerja. Karyawan dengan $t_{\text {hitung }}(10.451)>t_{\text {tabel }}(1,686)$ dan nilai signifikansi $(0.000)<$ taraf 
signifikansi $(0,05)$. Hasil pengujian koefisien korelasi menunjukkan ada korelasi antara Disiplin dengan Kinerja Karyawan sebesar $r=$ 0.861 (sangat kuat dan positif). Hasil pengujian koefisien determinasi menunjukkan bahwa pengaruh variabel independen yaitu Disiplin (X) terhadap variabel dependen yaitu Kinerja Karyawan adalah sebesar $74,2 \%$ dan sisanya $25,8 \%$ dipengaruhi oleh faktor lain.

\section{DAFTAR PUSTAKA}

Bangun, W. (2012). Manajemen Sumber Daya Manusia. Jakarta: Erlangga.

Bangun, W. (2014). Manajemen Sumber Daya Manusia. Jakarta: Erlangga.

Barnawi, \& Arifin, M. (2012). Strategi dan Kebijakan Pembelajaran Pendidikan Karakter. Jogjakarta: Ar-Ruzz.

Cleopatra, Efendi, D. L., \& Wijaya, A. (2015). Pengaruh Disiplin Kerja terhadap Kinerja Karyawan pada Pabrik Kerupuk Naga Mas Pematangsiantar. Jurnal Sultanist, 1-7.

Goble, F. G. (1995). The Third Force: The Psycology of Abraham Maslow, terjemahan A. Supratiknya, Mazhab Ketiga Psikologi Humanistik Abraham Maslow. Yogyakarta: Kanisius.

Hasibuan, M. S. (2016). Manajemen Sumber Daya Manusia. Jakarta: PT Bumi Aksara.

Hasibuan, M. S. (2018). Manajemen Sumber Daya Manusia. Jakarta: PT Bumi Aksara.

Mangkunegara, A. A. (2012). Manajemen Sumber Daya Manusia. Bandung: PT Remaja Rosdakarya.

Mangkunegara, A. A. (2013). Manajemen Sumber Daya Manusia. Bandung: PT Remaja Rosdakarya.

Moeheriono. (2012). Pengukuran Kinerja Berbasis Kompetensi. Jakarta: Raja Grafindo Persada.

Nurcahya, G. A., \& Sari, F. P. (2018). Pengaruh Disiplin Kerja terhadap Kinerja Karyawan PT Arah Environmental Indonesia Bag. Surakarta. e-Proceeding of Management, 303.
Rivai, \& Sagala, E. (2013). Manajemen Sumber Daya Manusia untuk Perusahaan. Jakarta: Rajawali Pers.

Septiasari, D. D. (2017). Pengaruh Disiplin Kerja terhadap Kinerja Pegawai pada Dinas Perindustrian Perdagangan, Koperasi, dan Usaha Mikro Kecil dan Menengah Provinsi Kalimantan Timur di Samarinda (Bidang Sekretariat dan Bidang Industri). e-Journal Administrasi Bisnis FISIP Universitas Mulawarman, 93-106.

Sinambela, L. P. (2012). Kinerja Pegawai. Yogyakarta: Graha Ilmu.

Sugiyono. (2013). Metode Penelitian Kuantitatif Kualitatif dan $R \& D$. Bandung: CV Alfabeta.

Sugiyono. (2018). Metode Penelitian Kuantitatif Kualitatif dan $R \& D$. Bandung: CV Alfabeta.

Sutrisno, E. (2014). Manajemen Sumber Daya Manusia. Jakarta: Kencana Prenada Media Group.

Sutrisno, E. (2015). Manajemen Sumber Daya Manusia. Jakarta: Kencana Prenada Media Group.

Sutrisno, E. (2016). Manajemen Sumber Daya Manusia. Jakarta: Kencana Prenada Media Group.

Wibowo. (2016). Perilaku dalam Organisasi. Jakarta: Raja Grafindo Persada. 